Research Article

\title{
Evaluation of the Active Support and Yielding Bearing Properties of Artificial Pillars Supporting a Stope Roof Using 3DEC Numerical Simulation
}

\author{
Kunmeng Li, Yuanhui Li (D), and Hongdi Jing \\ Key Laboratory of Ministry of Education on Safe Mining of Deep Metal Mines, Northeastern University, Shenyang 110819, China \\ Correspondence should be addressed to Yuanhui Li; 877260351@qq.com
}

Received 9 March 2019; Revised 22 October 2019; Accepted 8 November 2019; Published 7 December 2019

Academic Editor: Antonio Formisano

Copyright (c) 2019 Kunmeng Li et al. This is an open access article distributed under the Creative Commons Attribution License, which permits unrestricted use, distribution, and reproduction in any medium, provided the original work is properly cited.

\begin{abstract}
Before achieving yielding support with artificial pillars, it is significant to evaluate their active support and passive bearing performances on the stope roof. This paper focuses on three aspects of research using 3DEC numerical simulation, which are support patterns of artificial pillars, magnitude of support stresses, and the magnitude of prestresses of the load-increasing yielding support pattern. Simulation results show that the superior sequence of supporting effect is load-increasing yielding support, loadshedding yielding support, and constant and nonyielding support under the same initial support stress. When the magnitude of support stress or the magnitude of prestress is larger with load-increasing yielding support, the supporting effect is superior and the load-increasing yielding support with a lower magnitude of support stress is superior to some other support patterns with higher magnitude of support stresses. The active support can improve the support effect compared with no prestress, and under the same final support stress, the support effect is superior when the roof stress releases more in the early supporting stage regardless of the prestress.
\end{abstract}

\section{Introduction}

Pillar damage can be divided into structural failure and functional destruction. When the bearing stress on the pillar reaches its peak strength, the pillar begins to shed and yield, and this type of structural failure represents the decrease in the bearing capacity of the pillar, which results in the loss of the support capacity and the final functional destruction [1]. Between the beginning of yield and complete failure, the natural pillar is known as a "yielding pillar," which is first proposed for the room and pillar mining method to form a stress release region on the stope roof to reduce the load on the natural pillar [2]. Generally speaking, the small-sized pillar with a weak bearing capacity may be easily form the yielding support performance to stope roof, since the largesized pillar supports heavier load to limit the release of the roof stress, as shown in Figure 1.

Yielding pillars have been proposed and developed for many years in coal mines $[3,4]$ and hard rock mines $[5,6]$, which were proven to be economical and safe [7] because the size of pillars and the roof stress can be reduced and released. However, a yielding pillar is difficult to form because it must meet two basic characteristics; on the one hand, it must ensure that the pillar gradually yields, but not suddenly damaged, and on the other hand, the pillar needs to have enough residual strength to support the load of rock mass below the pressure arch $[5,8]$. Throughout the previous studies on the yielding pillars, which mainly focused on the failure process of natural pillars of different sizes by field observation and numerical simulation [9-12], since the stiffness of natural pillars is generally fixed, the pillar size becomes the only influencing factor to form yielding condition. However, the stiffness coordination relationship between the natural pillar and the stope roof is actually the foundation to achieve yielding support $[13,14]$. The artificial pillars are originally applied to replace the natural pillars for increasing the ore recovery rate [15-18]. With the development of mining technology, various categories of artificial 


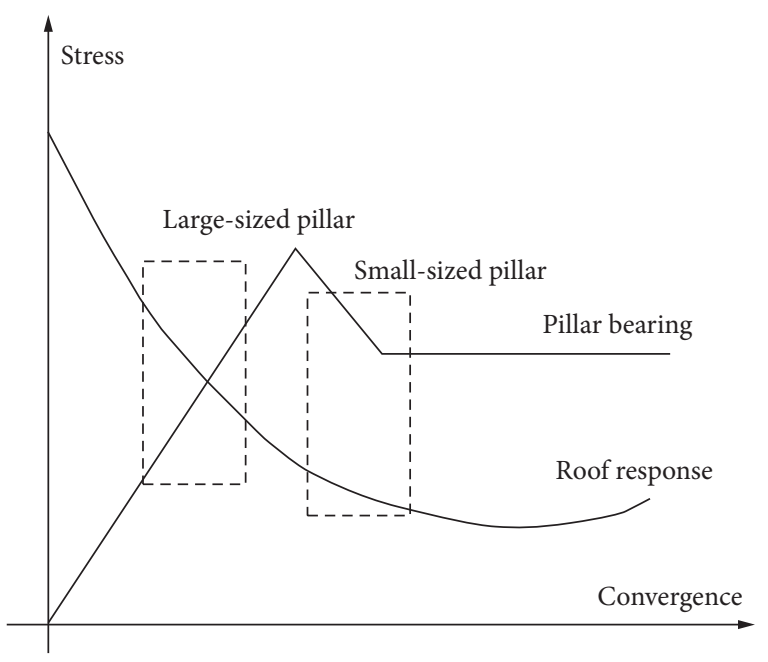

FIGURE 1: The relationship between the bearing stress of pillar and roof response.

pillars with different stiffness are designed to maximally adapt to the deformation of stope roof, and finally the yielding support is achieved to reduce the bearing load of pillars if the stress of stope roof is released reasonably.

The support patterns of artificial pillars involve passive bearing and active support [15]. The passive bearing property of artificial pillars can be divided into four categories [15]: nonyielding, constant yielding, load-shedding yielding, and load-increasing yielding support. The active support can provide a prestress relative to passive bearing, such as a Can support [19], in which prestress effectively limits the initial deformation of the stope roof. As a whole, the applied and studied artificial pillars mainly reflect the passive bearing performance [18-21]. However, the systematic analysis of roof responses under different active support and yielding bearing conditions is essential to optimize the support design of artificial pillars.

There are two methods, numerical simulation and onsite monitoring, to be applied to study the stope roof responses supported by various types of artificial pillars [20-23]. On-site monitoring is generally performed by installing pressure devices between the support bodies and stope roof, which is restricted to measuring the load bearing performances of specific artificial pillars. Nevertheless, a series of artificial support patterns, including the active support method, needs to be studied to reveal the interactions between the roof and artificial pillars. Compared with on-site monitoring, the numerical simulation method is more flexible, such as General Particle Dynamics (GPD) [24-27], Peridynamics(PD) [28-30], and the Extended Finite Element Method [31]. This paper uses 3-aldimension Distinct Element Code (3DEC) software to simulate the roof responses under different support conditions, and the support and yielding bearing performances of different kinds of support bodies are simulated by adjusting the reactive forces or stresses acting on the stope roof [31].

This paper mainly studies the active support and yielding bearing performances of artificial pillars. 14 projects are designed, which are, respectively, focused on the influences of support pattern, the magnitude of the support stresses, and the prestresses of load-increasing yielding support on the stope roof responses, including the stress state in the $Z$ axis direction and the plastic zone.

\section{Design of Numerical Model and Determination of Simulation Parameters}

As shown in Figures 2(a) and 2(b), the whole size of numerical model is three to ten times bigger than the excavated stope to eliminate the influence of boundary conditions on the results [31]. The reactive stresses are applied above and below the centre of stope over an area measuring $1.5 \mathrm{~m} \times 1.5 \mathrm{~m}$ to simulate the support function of artificial pillars. The top and lateral displacements of the model are restricted, and at the same time, the bottom is fixed. The monitoring points are located at $0.5 \mathrm{~m}$ above the stope roof, as shown in Figure 2(b), which is the profile of Figure 2(a) in the centre of model along the axis of the maximum horizontal stress.

The determination of rock mass parameters is an essential part of any numerical simulation. Typical goodquality rock masses are adopted based on the classification system of Bieniawski [32], and the strength parameters are calculated by evaluation method of Hoek and Brown $[33,34]$, as shown in Table 1 . Because the purpose of this paper is to explore the active support and yielding bearing performances of artificial pillars to stope roof, in order to simplify the simulation, the parameters of the orebody and host rock mass do not make a distinction.

The burial depth of the orebody is set to 300 , and the vertical stress, the maximum horizontal stress, and the minimum horizontal stress are, respectively, obtained by the following formulae: $S_{\mathrm{V}}=0.027 \mathrm{H}(\mathrm{MPa}), \quad K_{\mathrm{H}}=(150 / H+$ $1.4) \times S_{\mathrm{V}}$, and $K_{\mathrm{h}}=(128 / H+0.5) \times S_{\mathrm{V}}, H$ represents the burial depth $[35,36]$.

Different types of rock masses present different kinds of constitutive relationships. The selected rock mass of this paper is of high quality and behaves in an elastic-brittle manner $[37,38]$. This paper uses a strain softening constitutive model with stronger soften speed as an alternative of elastic-brittle manner because the 3DEC just comes with the former constitutive relationship, and the softening values are also shown in Table 1.

\section{Program Design}

In the process of numerical simulation, five types of support patterns are designed, as shown in Figure 3. A to D reflect the change of support stresses with different yielding support patterns, which separately are nonyielding, load-shedding yielding, constant yielding, and load-increasing yielding supports. In comparison with $\mathrm{D}, \mathrm{E}$ has a prestress. The abscissa of Figure 3 is the ratio of the running steps to the overall steps of numerical simulation, and the overall steps are the stable calculation steps (steps stable $_{\text {) }}$ when the stope is not supported. $X_{1}, X_{2}$, and $X_{3}$ are the ratios at the inflection points. The ordinate represents the change of support 


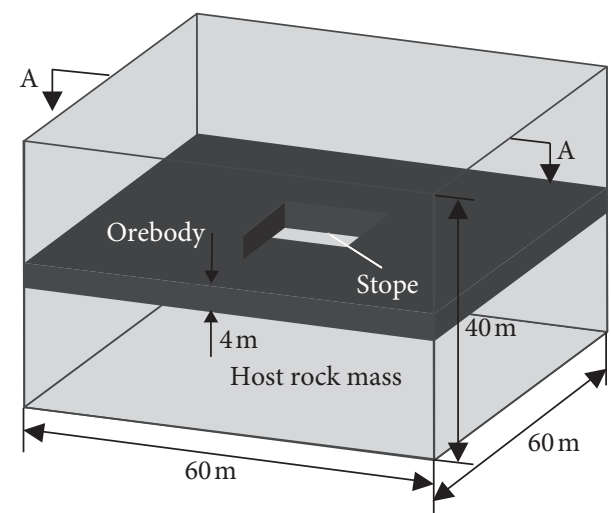

(a)

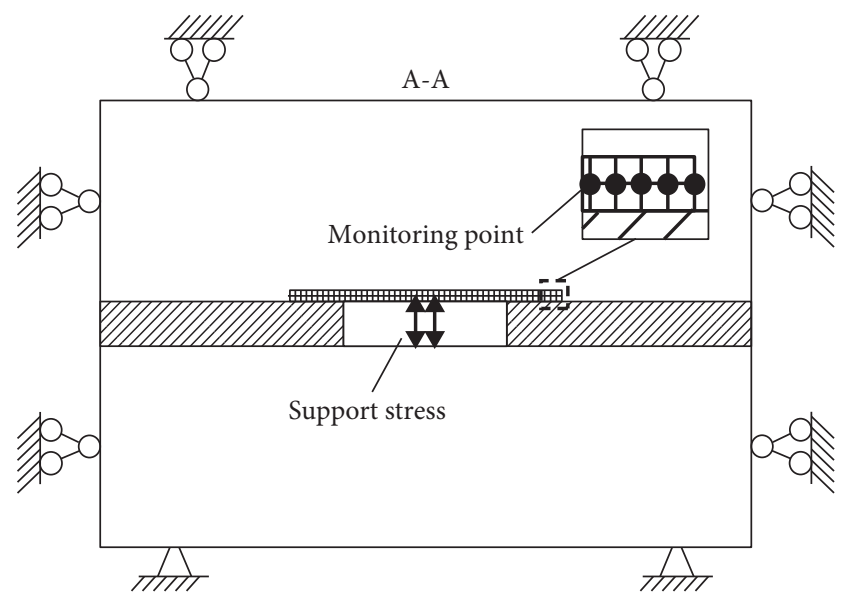

(b)

FIgURE 2: Numerical model size, boundary condition, and monitoring points designing. (a) Numerical model size. (b) Boundary condition and monitoring points designing.

TABLE 1: The determining parameters of rock mass.

\begin{tabular}{|c|c|c|c|c|c|c|c|c|c|c|}
\hline Parameters & $\begin{array}{l}\text { Density } \\
\left(\mathrm{kg} / \mathrm{m}^{3}\right)\end{array}$ & $\begin{array}{c}\text { Bulk } \\
\text { modulus } \\
(\mathrm{MPa})\end{array}$ & $\begin{array}{c}\text { Shear } \\
\text { modulus } \\
(\mathrm{MPa})\end{array}$ & $\begin{array}{l}\text { Tensile } \\
\text { strength } \\
(\mathrm{MPa})\end{array}$ & $\begin{array}{c}\text { Cohesion } \\
(\mathrm{MPa})\end{array}$ & $\begin{array}{c}\text { Residual } \\
\text { cohesion } \\
(\mathrm{MPa})\end{array}$ & $\begin{array}{c}\text { Friction } \\
\text { (deg) }\end{array}$ & $\begin{array}{c}\text { Residual } \\
\text { friction } \\
\text { (deg) }\end{array}$ & $\begin{array}{c}\text { Dilation } \\
\text { (deg) }\end{array}$ & $\begin{array}{c}\text { Residual } \\
\text { dilation } \\
(\mathrm{deg})\end{array}$ \\
\hline \multirow{2}{*}{$\begin{array}{l}\text { Pillar } \\
\text { Host rock } \\
\text { mass }\end{array}$} & 2700 & 12305.4 & 8472.54 & 0.36209 & 2.65 & 0.6625 & 38 & 9.5 & 20 & 5 \\
\hline & 2700 & 12305.4 & 8472.54 & 0.36209 & 2.65 & 0.6625 & 38 & 9.5 & 20 & 5 \\
\hline
\end{tabular}

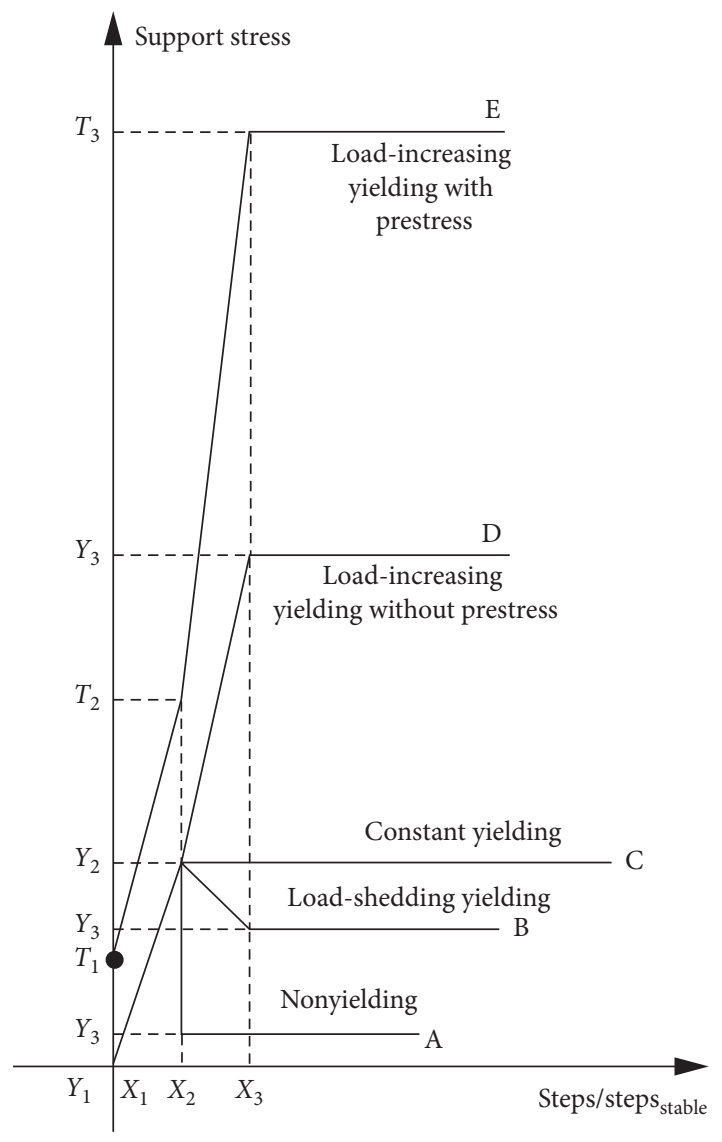

FIGURE 3: The designing of the support pattern. stresses, among them, $Y_{1}$ to $Y_{n}$ for $\mathrm{A}$ to $\mathrm{D}$ and $T_{1}$ to $T_{n}$ for $\mathrm{E}$ are the support stress values at the inflection points.

In order to analyze the active support and yielding bearing properties of artificial pillars to stope roof, 14 projects are designed as shown in Table 2. Projects 1 to 4 are focused on research into different types of support patterns. Projects 5 to 9 represent the magnitude change of the support stresses with load-increasing yielding support. Projects 10 to 14 reflect the influence of support effect with changing applied prestresses.

\section{Results and Analysis}

4.1. Support Pattern. Figure 4 shows the $Z$-direction stresses at $0.5 \mathrm{~m}$ above the roof with different support patterns, which corresponds to projects 1 to 4 . The abscissa represents the location of monitoring points, and the point at $0 \mathrm{~m}$ in the centre of stope. Compared with no support condition, although the other types of support patterns more or less restrict the stress release of stope roof, the affected scope of support is limited support layout area. The final stresses of stope roof are load-increasing yielding $>$ load-shedding yielding $>$ constant yielding and nonyielding support, and the stresses of stope roof with constant yielding and nonyielding support are almost equal, but none of them reach the stress state before rock mass is excavated. It is worth mentioning that the final stress of stope roof with loadshedding yielding support is larger than that with the constant yielding support, and the result can also be revealed through the observation of plastic zones, as shown in 
TABle 2: The designing program.

\begin{tabular}{|c|c|c|c|c|c|}
\hline Projects & Study point & $\begin{array}{l}\text { Types of } \\
\text { support }\end{array}$ & $\begin{array}{l}\text { Steps/steps } s_{\text {stable }} \\
\left(X_{1}, X_{2}, X_{3}\right)\end{array}$ & $\begin{array}{c}\text { Support stress }(\mathrm{MPa})\left(Y_{1}, Y_{1}, Y_{3}\right. \\
\left.\text { or } T_{1}, T_{2}, T_{3}\right)\end{array}$ & Remarks \\
\hline 1 & \multirow{4}{*}{ Support modes } & $\mathrm{A}$ & $0 \%, 1 \%, 2 \%$ & $0,0.1,0.01$ & \multirow{5}{*}{$\begin{array}{c}\text { Nonyielding } \\
\text { Load-shedding yielding } \\
\text { Constant yielding } \\
\text { Load-increasing yielding } \\
\text { without prestress }\end{array}$} \\
\hline 2 & & $\mathrm{~B}$ & $0 \%, 1 \%, 2 \%$ & $0,0.1,0.07$ & \\
\hline 3 & & $\mathrm{C}$ & $0 \%, 1 \%$ & $0,0.1$ & \\
\hline 4 & & $\mathrm{D}$ & $0 \%, 1 \%, 2 \%$ & $0,0.1,0.2$ & \\
\hline 05 & \multirow{5}{*}{$\begin{array}{l}\text { The magnitude of the } \\
\text { support stresses }\end{array}$} & $\mathrm{D}$ & $0 \%, 1 \%, 2 \%$ & $0,0.02,0.04$ & \\
\hline 6 & & $\mathrm{D}$ & $0 \%, 1 \%, 2 \%$ & $0,0.03,0.06$ & \multirow{3}{*}{$\begin{array}{l}\text { Load-increasing yielding } \\
\text { without prestress }\end{array}$} \\
\hline 7 & & $\mathrm{D}$ & $0 \%, 1 \%, 2 \%$ & $0,0.04,0.08$ & \\
\hline 8 & & $\mathrm{D}$ & $0 \%, 1 \%, 2 \%$ & $0,0.05,0.1$ & \\
\hline 9 & & $\mathrm{D}$ & $0 \%, 1 \%, 2 \%$ & $0,0.06,0.12$ & \multirow{6}{*}{$\begin{array}{c}\text { Load-increasing yielding with } \\
\text { prestress }\end{array}$} \\
\hline 10 & \multirow{5}{*}{$\begin{array}{c}\text { The magnitude of the } \\
\text { prestresses }\end{array}$} & $\mathrm{E}$ & $0 \%, 1 \%, 2 \%$ & $0.005,0.01,0.02$ & \\
\hline 11 & & $\mathrm{E}$ & $0 \%, 1 \%, 2 \%$ & $0.01,0.02,0.04$ & \\
\hline 12 & & $\mathrm{E}$ & $0 \%, 1 \%, 2 \%$ & $0.02,0.04,0.07$ & \\
\hline 13 & & $\mathrm{E}$ & $0 \%, 1 \%, 2 \%$ & $0.03,0.06,0.1$ & \\
\hline 14 & & $\mathrm{E}$ & $0 \%, 1 \%, 2 \%$ & $0.04,0.08,0.13$ & \\
\hline
\end{tabular}

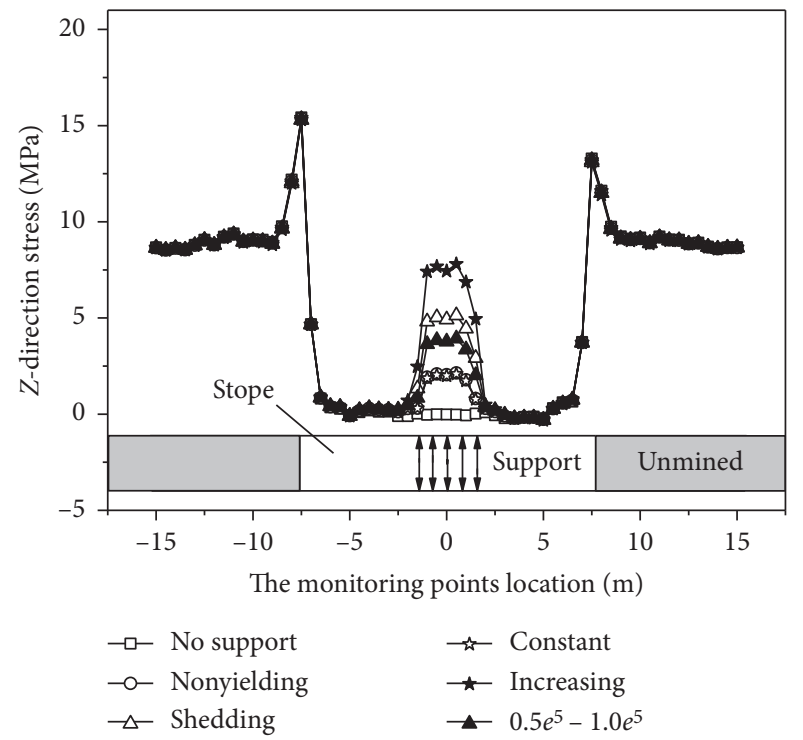

Figure 4: The $Z$-direction stress with different patterns.

Figure 5, which shows the plastic zones of stope roof in section A-A of Figure 2 under different support patterns. The plastic zone of stope roof presents a pressure arch under nonsupporting condition, and the arch is cut but not completely separated with the nonyielding and constant yielding support; nevertheless, the arch is absolutely open with load-shedding and load-increasing yielding support.

Firstly, the support role limits roof deformation, restricts roof stress release, and prevents stope failures compared with nonsupporting condition; this appropriate release of roof stress does not violate the concept of yielding support, because the support force of pillars does not keep going down. Secondly, although the support stress of the load-shedding yielding pattern decreases slightly, which is a necessary condition for stope roof to release more stress, the reduced support stress can resist residual load of stope roof. Relatively speaking, the support stress does not decrease with constant yielding support which is larger than that with the load-

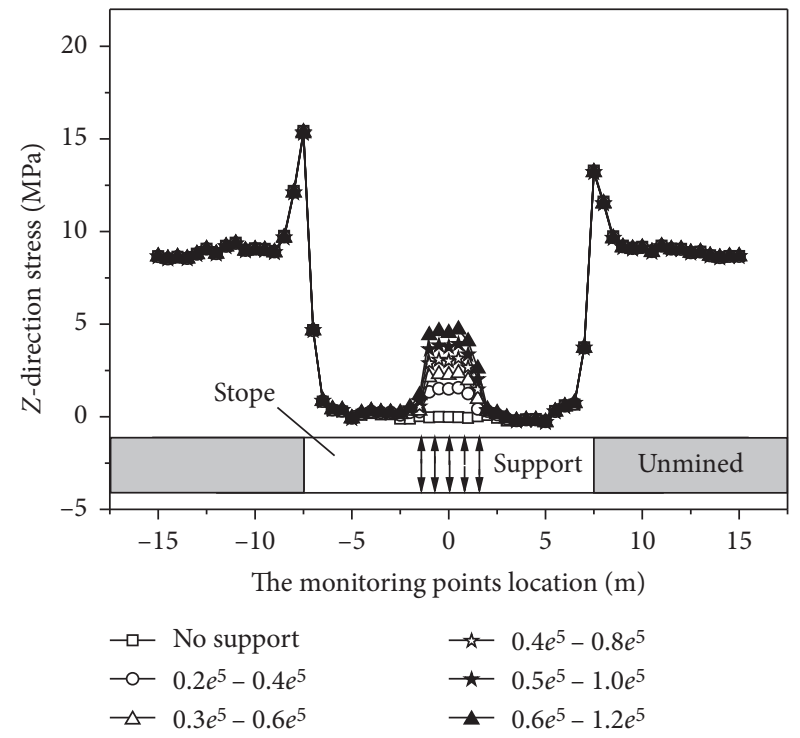

Figure 5: The plastic zones. (a) Nonsupporting. (b) Nonyielding. (c) Load-shedding yielding. (d) Constant yielding. (e) Load-increasing yielding. (f) Load-increasing yielding $\left(0.5 e^{5}-1.0 e^{5}\right)$.

shedding support in the later support stage, but which supports the roof with a more burdensome stope roof load because the stress of roof does not have the chance to release more, so the final stress of stope roof with load-shedding yielding support is higher than that with constant yielding support. In fact, the nonyielding support pattern can be considered as another type of load-shedding yielding support, and the difference is that the support stress reduces too much with a nonyielding support, which results in the final support stress being unable to support the residual load of roof although the stress of roof is released to a greater extent. Therefore, the final stress of stope roof with a load-shedding yielding support is larger than with a nonyielding support. For the load-increasing yielding support, the support stress increases in the later period than other support patterns, 


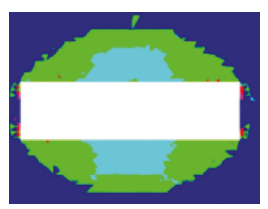

(a)

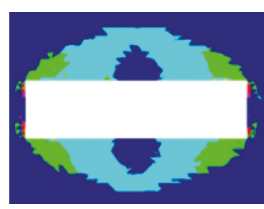

(b)

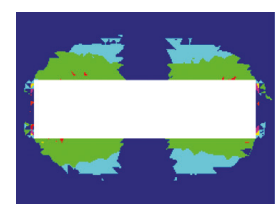

(c)

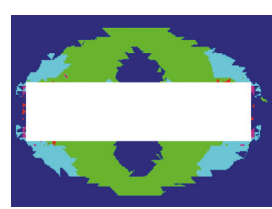

(d)

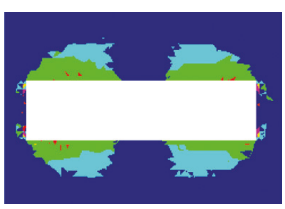

(e)

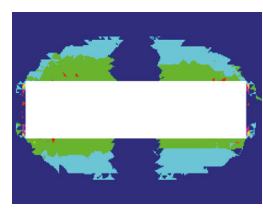

(f)

Figure 6: The $Z$-direction stress with different support stresses.

although which prevents the roof stress being released further, the increased support stress supports more heavily loaded roof, so the final stress of stope roof is largest.

4.2. The Magnitude of the Support Stresses. Besides the support pattern, the magnitude of the support stresses is another factor to influence the support effect. Figure 6 shows the stresses in the $Z$-direction at $0.5 \mathrm{~m}$ above the stope roof with different magnitudes of support stresses with a loadincreasing yielding support, the support stresses are shown in projects 5 to 9 of Table 2, and the increments in bearing support stresses of all projects are designed to increase as the initial support stresses increase. In order to compare the load-increasing yielding support having lower magnitude of stress with other support patterns having higher magnitude of stresses, the load-increasing yielding supports project 8 with support stress from $0.05 \mathrm{MPa}$ to $0.1 \mathrm{MPa}$ is added to Figure 4.

As shown in Figure 6, as the magnitude of the support stress increases, the stress of stope roof increases, and the plastic zone is fully open with support stress from $0.05 \mathrm{MPa}$ to $0.1 \mathrm{MPa}$, as shown in Figure 5(f). The stress of roof with a load-increasing yielding support offering $0.05 \mathrm{MPa}$ to $0.1 \mathrm{MPa}$ is larger than that with a nonyielding and constant yielding support (projects 1 and 3 ) and less than that with a load-shedding yielding support (project 2), as shown in Figure 4.

With the load-increasing yielding support, the support body exerts a much greater stress release restriction to the roof, so the stress of stope roof is larger. Although the final support stresses are all kept at $0.1 \mathrm{MPa}$ in the follow-up phase between the constant yielding support of project 3 and loadincreasing yielding support from $0.05 \mathrm{MPa}$ to $0.1 \mathrm{MPa}$, the support stress of the latter project is smaller in the previous support stage, the stress on roof releases earlier and to a greater extent, so this support pattern does not need to support more highly stressed roof, and the final stress of roof is larger. The stress is released to a greater extent in the followup supporting phase with a smaller support stress with a loadshedding yielding support, which results that the final support stress does not need to be too high to support the roof, so the stress of stope roof with a load-shedding yielding support is larger than that that with a load-increasing yielding support offering from $0.05 \mathrm{MPa}$ to $0.1 \mathrm{MPa}$ (Figure 4).

Overall, the support effect is superior when the magnitude of support stress is bigger with a load-increasing yielding support, and the load-increasing yielding support with a lower magnitude of support stress has better support effect than other support patterns with larger support stresses.

4.3. The Magnitude of the Applied Prestresses. The active support effect of a support body with an applied prestress is another research objective, as shown in projects 10-14 (Table 2), five kinds of prestress with a load-increasing yielding support are designed, and the increment of support stress is designed to increase with the initial applied prestress increasing. Figure 7 shows the simulation results, the stress of stope roof increases with increase in the prestress, and the plastic zone can be fully open at $0.03 \mathrm{MPa}$ and from $0.06 \mathrm{MPa}$ to $0.1 \mathrm{MPa}$, in which the support effect is superior to the constant yielding support of project 3 and worse than the load-increasing yielding support of project 4 according to the final stresses of stope roof. The stress of roof with the load-increasing yielding support at $0.0 \mathrm{MPa}$ and from $0.05 \mathrm{MPa}$ to $0.1 \mathrm{MPa}$ without prestress in project 4 is less than $0.04 \mathrm{MPa}$ and from $0.08 \mathrm{MPa}$ to $0.13 \mathrm{MPa}$ with an applied prestress, as shown in Figure 8.

The prestress and the final support stress are higher, resulting that the final stress of roof is larger. Although the final support stresses are all $0.1 \mathrm{MPa}$ and a load-increasing yielding support offering $0.03 \mathrm{MPa}$ and from $0.06 \mathrm{MPa}$ to $0.1 \mathrm{MPa}$ has an applied prestress, the support stress at the first inflection point and the overall support stress of a loadincreasing yielding support with $0.03 \mathrm{MPa}$ and from $0.06 \mathrm{MPa}$ to $0.1 \mathrm{MPa}$ before the final support stress is stable are smaller than the stress with constant yielding support of project 3, which causes the former to release more stress of stope roof, and the support body no longer needs support more powerful stress roof in the late supporting period, so the roof stress of the former project is larger than the latter project. The reason why the stress of roof with a load-increasing yielding support without prestress of project 8 is bigger than that with a load-increasing yielding support with a $0.03 \mathrm{MPa}$ applied prestress is that the former releases more stress early in the supporting stage although the final support stresses are the same. To sum up, under the same final support stress, the support effect is superior when the stress on the roof is released to a greater extent regardless of the applied prestress. At $0.0 \mathrm{MPa}$ and from $0.05 \mathrm{MPa}$ to $0.1 \mathrm{MPa}$ without prestress and $0.04 \mathrm{MPa}$ and from $0.08 \mathrm{MPa}$ to $0.13 \mathrm{MPa}$ with prestress, they have the same incremental value or the increment value of former support method is bigger in the load bearing process, because the applied prestress can limit the initial deformation of the roof, and the overall support stress of the latter support pattern is larger, 


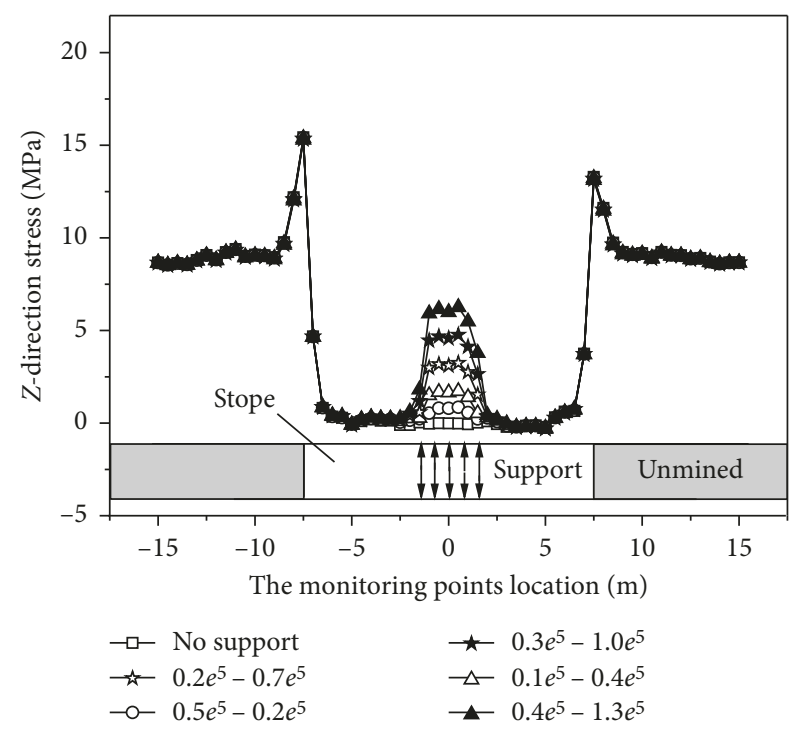

Figure 7: The $Z$-direction stress with different prestresses.

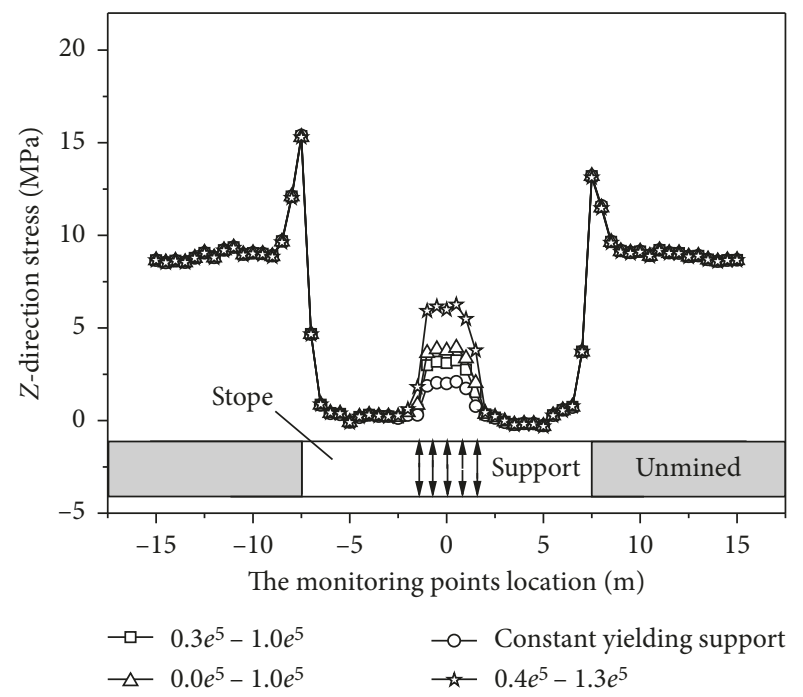

FIgURE 8: The $Z$-direction stress with different support methods.

so the stress of roof with former support is less than that with the latter support, which proves that an active support is beneficial compared to other support patterns without an applied prestress.

\section{Conclusions}

This paper focuses on the analysis of the active support and yielding bearing properties of artificial pillars to the stope roof. The conclusions are as follows:

(1) The load-shedding yielding support with proper stress release of stope roof is superior to constant and no-yielding support, and the load-increasing yielding support is superior to other support methods under the same initial support stress

(2) The support effect is superior when the magnitude of the support stress is greater with load-increasing yielding support, and the load-increasing yielding support with a smaller magnitude of support stresses can be superior to some other support patterns with higher magnitude support stresses

(3) With load-increasing yielding support, the bigger the prestress is, the better support effect can be obtained, and the active support can improve support effect of a stope roof relative to other support patterns without prestress

(4) Under the same final support stresses, the support effect is superior when the roof releases more stress under same support conditions, regardless of the prestress

\section{Data Availability}

The data used to support the findings of this study are included within the article.

\section{Conflicts of Interest}

The authors declare that there are no conflicts of interest regarding the publication of this paper.

\section{Acknowledgments}

This work was supported by the National Natural Science Foundation of China (grant no. 51674061), the State Key Research Development Program of China (grant no. 2018YFC0604601), and the Program for Innovative Talents in Liaoning University (grant no. LR2016024).

\section{References}

[1] E. Esterhuizen, C. Mark, and M. M. Murphy, "The ground response curve, pillar loading and pillar failure in coal mines," in Proceedings of the 29th International Conference on Ground Control in Mining, Morgantown, WV, USA, July 2010.

[2] H. Yavuz, "Yielding pillar concept and its design," in Proceedings of the 17th International Mining Congress and Exhibition of Turkey, Ankara, Turkey, June 2001.

[3] C. Mark, J. Listak, and Z. T. Bieniawski, "Yielding coal pillarsfield measurements and analysis of design methods," in Proceedings of the 29th U.S. Symposium on Rock Mechanics (USRMS), Minneapolis, MN, USA, June 1988.

[4] A. T. Iannacchione and J. C. Zelanko, "Occurrence and remediation of coal mine bumps: a historical review," in Proceedings of the Mechanics and Mitigation of Violent Failure in Coal and Hard-Rock Mines, Spokane, PA, USA, May 1995.

[5] G. Barrientos and J. Parker, "Use of the pressure arch in mine design at white pine," The American Institute of Mining, Metallurgical, and Petroleum Engineers, vol. 256, pp. 1-8, 1975.

[6] J. A. Ryder and M. U. Ozbay, "A methodology for designing pillar layouts for shallow mining," in Proceedings of the ISRM International Symposium on Static and Dynamic Considerations in Rock Engineering, Swaziland, September 1990.

[7] N. P. Kripakov, M. C. Sun, and D. A. Donato, "Automation of a progressive failure procedure for analysis of underground mine pillar designs," in Proceedings of the International 
Conference on Ground Control in Mining, Morgantown, WV, USA, August 1994.

[8] C. T. Holland, Mine Pillar Design, SME Mining Engineering Handbook, Society for Mining, Metallurgy, and Exploration, Englewood, CO, USA, 1973.

[9] A. Mortazavi, F. P. Hassani, and M. Shabani, "A numerical investigation of rock pillar failure mechanism in underground openings," Computers and Geotechnics, vol. 36, no. 5, pp. 691-697, 2009.

[10] T. Ma, L. Wang, F. T. Suorineni, and C. Tang, "Numerical analysis on failure modes and mechanisms of mine pillars under shear loading," Shock and Vibration, vol. 2016, Article ID 6195482, 14 pages, 2016.

[11] C. D. Martin and W. G. Maybee, "The strength of hard-rock pillars," International Journal of Rock Mechanics and Mining Sciences, vol. 37, no. 8, pp. 1239-1246, 2000.

[12] G. S. Esterhuizen, D. R. Dolinar, and J. L. Ellenberger, "Pillar strength and design methodology for stone mines," in Proceedings of the 27th International Conference on Ground Control in Mining, Morgantown, WV, USA, July 2008.

[13] M. D. G. Salamon, "Stability, instability and design of pillar workings," International Journal of Rock Mechanics and Mining Sciences \& Geomechanics Abstracts, vol. 7, no. 6, pp. 613-631, 1970.

[14] R. Karl and R. K. Zipf, "Pillar design to prevent collapse of room-and-pillar mines," in Underground Mining Methods: Engineering Fundamentals and International Case Studies, pp. 493-511, Society for Mining Metallurgy and Exploration, Englewood, CO, USA, 2001.

[15] T. M. Barczak, "An overview of standing roof support practices and developments in the United States," in Proceedings of the Third South African Rock Engineering Symposium, Johannesburg, South Africa, January 2005.

[16] S. C. Tadolini and T. M. Barczak, "Design parameters of roof support systems for pre-driven longwall recovery rooms," in Proceedings of the SME Annual Meeting, Pittsburgh, PA, USA, February 2004.

[17] C. Mark, D. R. Dolinar, R. J. Tuchman, T. M. Barczak, S. P. Signer, and P. F. Wopat, "New technology for coal mine roof support," in Proceedings of the New Technology for Coal Mine Roof Support, Pittsburgh, PA, USA, October 2000.

[18] D. R. Dolinar, "Ground and standing support interaction in tailgates of western U.S. longwall mines used in the development of a design methodology based on the ground reaction curve," in Proceedings of the 29th International Conference on Ground Control in Mining, Morgantown, WV, USA, July 2010.

[19] T. M. Barczak, S. C. Tadolini, and P. McKelvey, "Hydraulic prestressing units: an innovation in roof support technology," in Proceedings of 23rd International Conference on Ground Control in Mining, Morgantown, WV, USA, August 2004.

[20] T. M. Barczak, G. S. Esterhuizen, and J. Ellenberger, “A first step in developing standing roof support design criteria based on ground reaction data for Pittsburgh seam longwall tailgate support," in Proceedings of the 27th International Conference on Ground Control in Mining, Morgantown, WV, USA, July 2008.

[21] D. R. Dolinar, T. M. Barczak, and H. Gurley, "Evaluation of tailgate standing support interaction in the Illinois basin for the development of a ground reaction curve based standing support design," in Proceedings of the 28th International Conference on Ground Control in Mining, Morgantown, WV, USA, July 2009.
[22] E. Esterhuizen, C. Mark, and M. M. Murphy, "Numerical model calibration for simulating coal pillars, gob and overburden response," in Proceedings of the 28th International Conference on Ground Control in Mining, Morgantown, WV, USA, July 2010.

[23] M. R. Asef, D. J. Reddish, and P. W. Lloyd, "Rock-support interaction analysis based on numerical modelling," Geotechnical and Geological Engineering, vol. 18, no. 1, pp. 23-37, 2000.

[24] J. Bi, X. P. Zhou, and X. M. Xu, "Numerical simulation of failure process of rock-like materials subjected to impact loads," International Journal of Geomechanics, vol. 17, no. 3, Article ID 04016073, 2017.

[25] J. Bi, X. P. Zhou, and Q. H. Qian, "The 3D numerical simulation for the propagation process of multiple pre-existing flaws in rock-like materials subjected to biaxial compressive loads," Rock Mechanics and Rock Engineering, vol. 49, no. 5, pp. 1611-1627, 2016.

[26] X. P. Zhou, J. Bi, and Q. H. Qian, "Numerical simulation of crack growth and coalescence in rock-like materials containing multiple pre-existing flaws," Rock Mechanics and Rock Engineering, vol. 48, no. 3, pp. 1097-1114, 2015.

[27] Y. Wang, X. Zhou, and X. Xu, "Numerical simulation of propagation and coalescence of flaws in rock materials under compressive loads using the extended non-ordinary statebased peridynamics," Engineering Fracture Mechanics, vol. 163, pp. 248-273, 2016.

[28] X.-P. Zhou, X.-B. Gu, and Y.-T. Wang, "Numerical simulations of propagation, bifurcation and coalescence of cracks in rocks," International Journal of Rock Mechanics and Mining Sciences, vol. 80, pp. 241-254, 2015.

[29] Y. Wang, X. Zhou, Y. Wang, and Y. Shou, “A 3-D conjugated bond-pair-based peridynamic formulation for initiation and propagation of cracks in brittle solids," International Journal of Solids and Structures, vol. 137, pp. 89-115, 2018.

[30] X. P. Zhou and H. Q. Yang, "Multiscale numerical modeling of propagation and coalescence of multiple cracks in rock masses," International Journal of Rock Mechanics and Mining Sciences, vol. 55, pp. 15-27, 2012.

[31] Itasca Consulting Group, Inc., 3-Dimensional Distinct Element Code, Theory and Background, Itasca, Minneapolis, MN, USA, 1998.

[32] Z. T. Bieniawski, Engineering Rock Mass Classifications, Wiley-Interscience, New York, NY, USA, 1989.

[33] E. Hoek and E. T. Brown, "The Hoek-Brown failure criterion: a 1988 update," in Proceedings of the 15th Canadian Rock Mechanics Symposium, Toronto, Canada, October 1988.

[34] E. Hoek, "Strength of rock and rock masses," ISRM News Journal, vol. 2, no. 2, pp. 4-16, 1994.

[35] E. T. Brown and E. Hoek, "Trends in relationships between measured in-situ stresses and depth," International Journal of Rock Mechanics and Mining Sciences \& Geomechanics Abstracts, vol. 15, no. 4, pp. 211-215, 1978.

[36] F. Li, "In situ stress state in Mainland China," Pure and Applied Geophysics PAGEOPH, vol. 145, no. 3-4, pp. 775-787, 1995.

[37] E. Hoek, P. K. Kaiser, and W. F. Bawden, Support of Underground Excavations in Hard Rock, Rotterdam, Netherlands, 1995.

[38] E. Hoek and E. Brown, "Practical estimates of rock mass strength," International Journal of Rock Mechanics and Mining Science \& Geomechanics Abstracts, vol. 34, no. 8, pp. 1165-1186, 1997. 


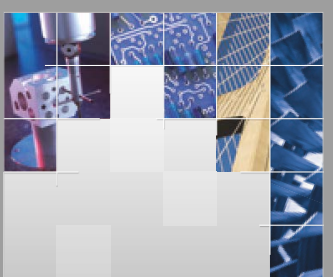

\section{Enfincering}
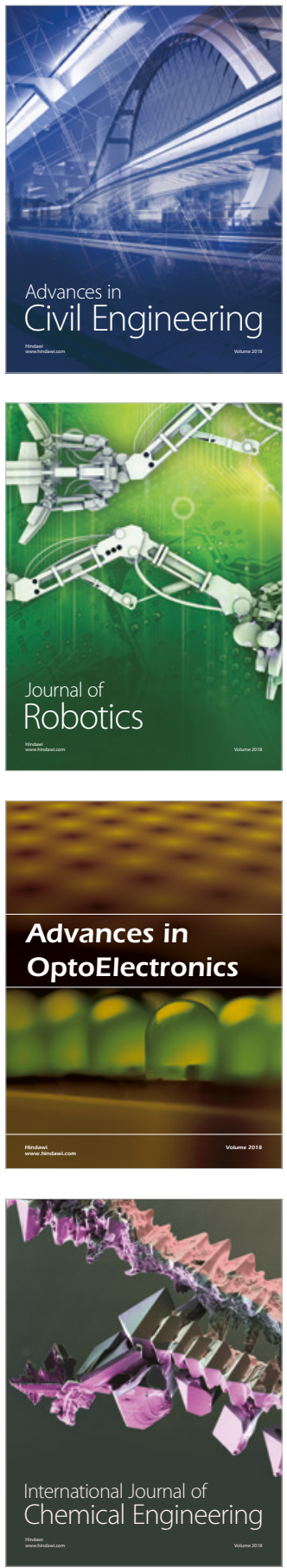

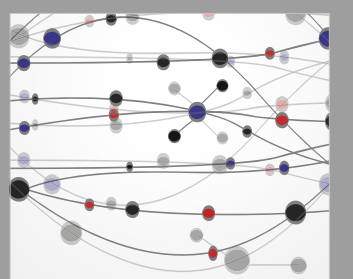

\section{Rotating \\ Machinery}

The Scientific World Journal

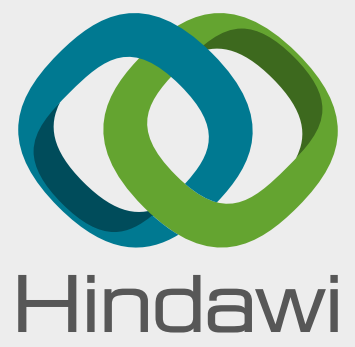

Submit your manuscripts at

www.hindawi.com
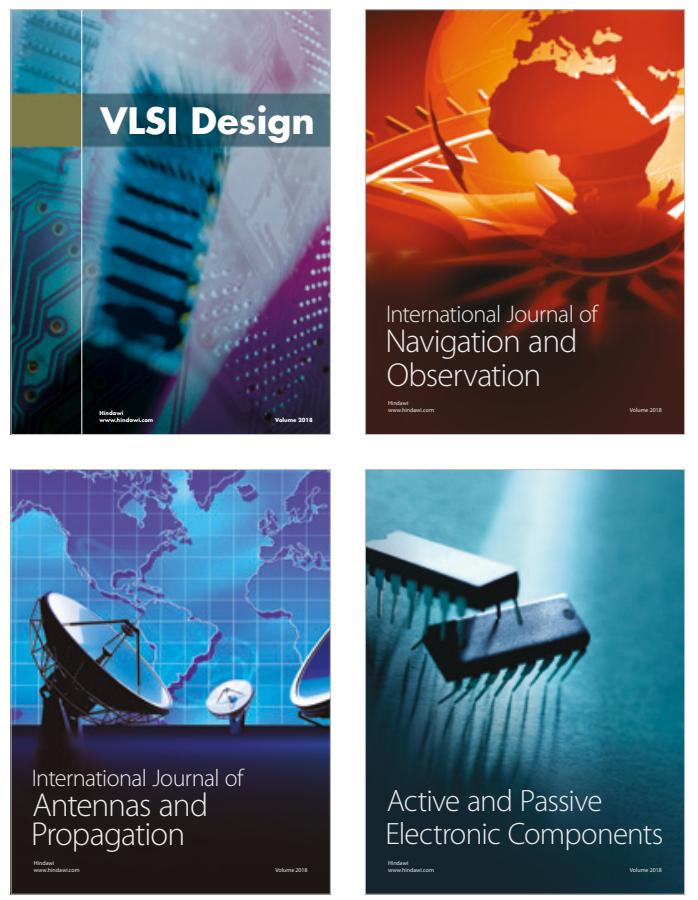
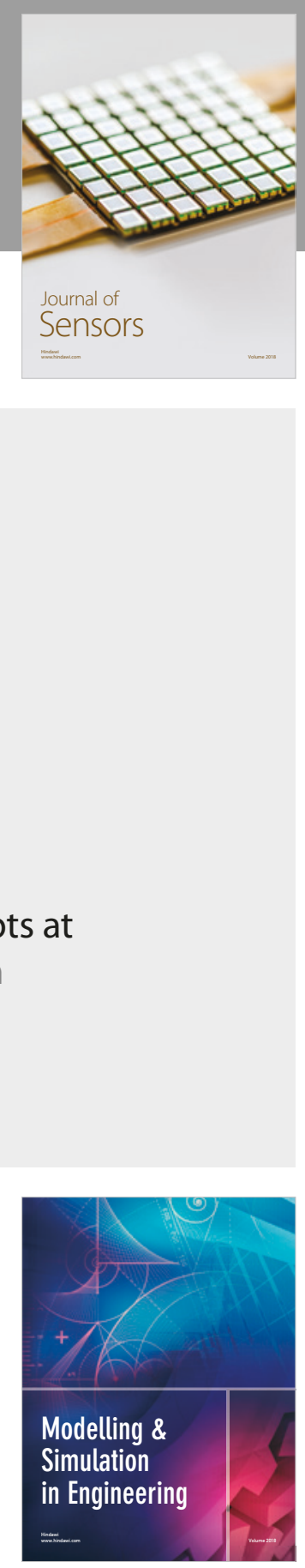

\section{Advances \\ Multimedia}
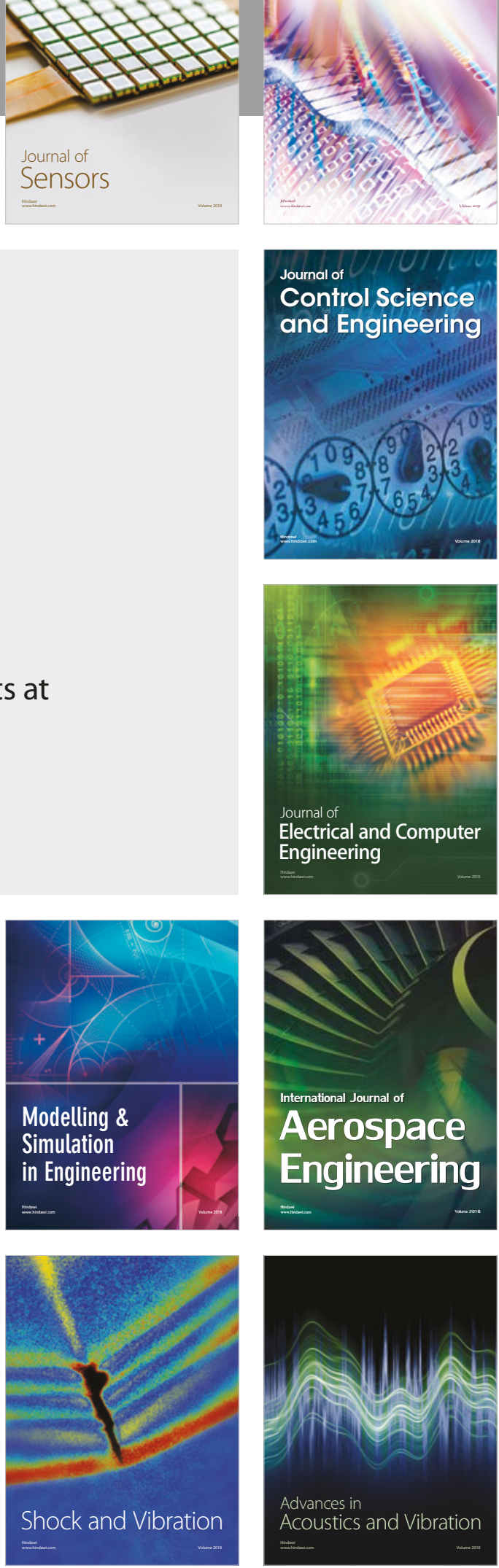